\title{
PREDIKSI VOLATILITAS HARGA JUAL PRODUK PADA E-COMMERCE UNTUK INDEPENDENT STOCKASHTIC DATA MENGGUNAKAN SIMULASI MONTE CARLO
}

\author{
Erlangga Bayu Setyawan ${ }^{1)}$, Nia Novitasari ${ }^{2)}$, Prafajar Suksessanno Muttaqin ${ }^{3)}$ \\ Program Studi Teknik Logistik, Universitas Telkom \\ Email:erlanggabs@telkomuniversity.ac.id ${ }^{1)}$, novitasarinia@telkomuniversity.ac.id ${ }^{2)}$, prafajars@telkomuniversity.ac.id ${ }^{3)}$
}

\begin{abstract}
ABSTRAK
Perkembangan dan penggunaan inovasi teknologi tersebut juga telah mengubah perilaku masyarakat dari masyarakat industri menuju masyarakat informasi. Perubahan tersebut dapat terlihat dengan adanya peningkatan pola konsumsi masyarakat dari perdagangan melalui toko fisik (offline) beralih ke perdagangan melalui sistem elektronik atau sering disebut sebagai e-commerce. Jasa logistik merupakan pemeran distribusi di lini downstream dimana bertugas untuk mengantarkan produk dari fulfillment center dari suatu e-commerce menuju ke end customer. Jasa logistik dituntut harus dapat melakuan pemenuhan permintaan dari konsumen sesuai dengan service level agreement (SLA). Tidak menentunya jumlah permintaan menjadi tantangan yang paling besar bagi pemeran jasa logistik. Seperti studi kasus yang digunakan pada penelitian ini, PT ABC mengalami overload ketika melakukan pemenuhan permintaan dari e-commerce PT XYZ. Overload tersebut dikarenakan ketidaksiapan PT ABC dalam menangani lonjakan permintaan yang signifikan karena perubahan harga jual Produk A di e-commerce PT XYZ. Pada penelitian ini diusulkan model peramalan harga jual Produk A pada e-commerce PT XYZ menggunakan model Simulasi Monte Carlo Independent Variable. Simulasi dilakukan dengan 1.000 percobaan dan menghasilkan MAPE terendah pada percobaan 322, yaitu, $0,122 \%$.
\end{abstract}

Kata kunci: E-Commerce, Forecasting, Monte Carlo, Revolusi Industri

\section{Pendahuluan}

Revolusi industri 4.0 telah berhasil menciptakan inovasi di segala lini menuju ke era digital, baik lini upstream, middle stream, maupun downstream. Inovasi tersebut dilakukan untuk menciptakan aktivitas menjadi lebih efektif dan efisien dalam melakukan proses pemenuhan permintaan dari konsumen. Perkembangan dan penggunaan inovasi teknologi tersebut juga telah mengubah perilaku masyarakat dari masyarakat industri menuju masyarakat informasi. Contoh perubahan tersebut dapat terlihat dengan adanya peningkatan pola konsumsi masyarakat dari perdagangan melalui toko fisik (offline) beralih ke perdagangan melalui sistem elektronik atau sering disebut sebagai e-commerce [1]. Hal yang sama juga terjadi di Indonesia, bahkan McKinsey (2018) meramalkan nilai transaksi e-Commerce di Indonesia akan meningkat hingga delapan kali lipat, dari USD 8 Milyar pada tahun 2017 menjadi USD 55 - 65 Milyar pada tahun 2022. Berdasarkan data dari Kementerian Komunikasi dan Informasi Republik Indonesia, pada tahun 2019, tingkat pertumbuhan nilai transaksi e-commerce Indonesia adalah sebesar $78 \%$ apabila dibandingkan dengan tahun 2018 [2]. Selain itu, Kemkominfo juga mengeluarkan data bahwa Indonesia menduduki ranking pertama di dunia, sesuai data yang disajikan pada Gambar 1.

Data Pertumbuhan E-Commerce

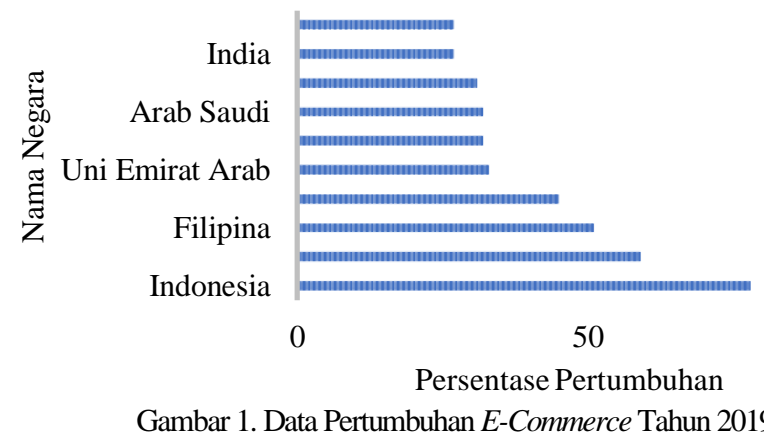

Copyright (C) 2020, Kaizen : Management Systems \& Industrial Engineering Journal ISSN 15222-96806 (print), ISSN $155222-95973$ (online) 


\section{KAIZEN : MANAGEMENT SYSTEMS \& INDUSTRIAL ENGINEERING JOURNAL VOL. 3 NO. 1 TEKNIK INDUSTRI UNIVERSITAS PGRI MADIUN}

Revolusi Indutri 4.0 yang telah diuraikan di atas hingga dewasa ini mengubah pola perdagangan konvensional menjadi perdagangan melalui sistem elektronik, mendorong perubahan bentuk industri logistik terutama logistik ritel. Evolusi logistik ritel berawal dari pengiriman barang secara langsung dari pemasok ke pengecer (tahun 1970-an), berkembang menjadi penggunaan pusat distribusi (tahun 1980-an), perkembangan ke arah global sourcing (tahun 1990-an), dan digitalisasi sistem logistik yang mendukung e-commerce, seperti berkembangnya e-fulfillment centers, parcel hub, sortation centers, parcel delivery centers, local depots, collection dan delivery point [3]. Evolusi logistik retail ini juga seiring dengan perkembangan Industri 4.0, yang berimplikasi pada perubahan manajemen aliran barang, informasi dan uang. Perubahan sistem logistik ini dikenal dengan logistics 4.0 yang tercermin oleh semakin kuatnya penggunaan TIK yang berkembang pada era Industri 4.0 untuk mendukung sistem logistik seperti penggunaan IoT, robot, teknologi awan, blockchain dan teknologi lainnya. Perubahan ini selanjutnya berimplikasi pada tuntutan kompetensi sumber daya manusia yang dibutuhkan di setiap pemangku kepentingan terkait di bidang logistik.

Jasa logistik merupakan pemeran distribusi di lini downstream dimana bertugas untuk mengantarkan produk dari fulfillment center dari suatu e-commerce menuju ke end customer. Jasa logistik dituntut harus dapat melakuan pemenuhan permintaan dari konsumen sesuai dengan Service Level Agreement (SLA). SLA akan menjadi lebih ketat apabila jasa logistik tersebut merupakan jasa logistik yang terdedikasikan untuk suatu e-commerce tertentu. Hal tersebut dikarenakan apabila terjadi wan prestasi pada saat pengiriman, nama baik e-commerce tersebut juga ikut dipertaruhkan.

Penelitian ini akan membahas salah satu cara yang dilakukan oleh jasa logistik untuk menjaga SLA pengiriman produk, yaitu, mengetahui jumlah produk yang harus ditangani dalam suatu satuan waktu tertentu. Semakin banyak produk yang harus ditangani dari suatu fulfillment center, maka akan semakin tinggi beban kerja. Untuk melakukan penelitian ini, penulis menggunakan studi kasus PT ABC dan PT XYZ, dimana PT ABC adalah penyedia jasa logistik yang terdedikasi untuk melayani pengiriman produk dari e-commerce PT XYZ. Dalam melakukan pemenuhan permintaan dari fulfillment center PT XYZ menuju end customer, tingkat service level PT ABC hanya 72\%, ditampilkan pada Gambar 2a. Penyebab 28\% tidak terpenuhinya service level didominasi oleh terjadinya pemesanan yang overload, yang ditampilkan pada Gambar $2 \mathrm{~b}$.

\section{Service Level}

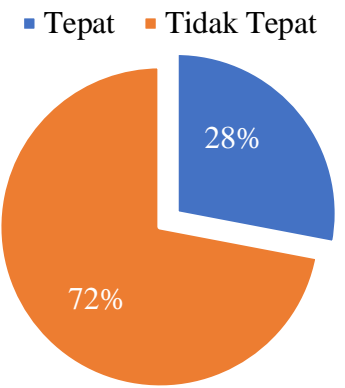

(a)

\section{Penyebab Terjadinya Keterlambatan}

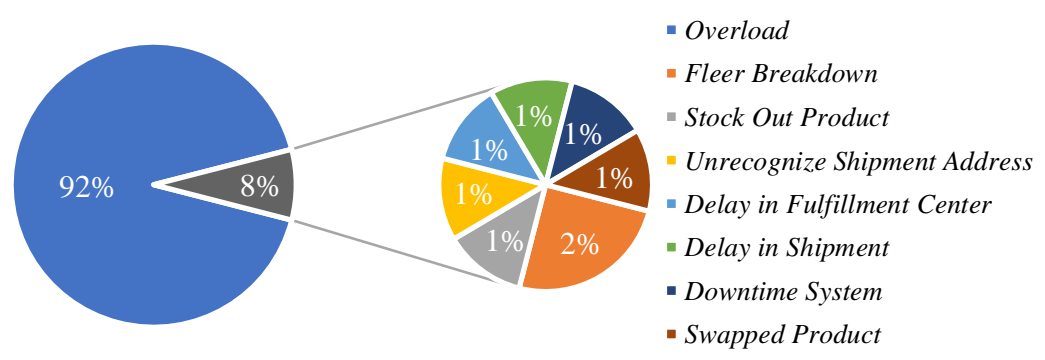

(b)

Gambar 2. Tingkat Service Level (a) dan Penyebab Terjadinya Keterlambatan (b) di PT ABC

Setelah dilakukan pengpenelitian lebih dalam, penyebab terjadinya lonjakan pemesanan sehingga menyebabkan overload pada e-commerce PT XYZ adalah terjadinya perubahan harga yang signifikan. PT XYZ merupakan ecommerce yang menjual imported brand dimana menggunakan kurs USD untuk melakukan transaksi, sehingga kurs dolar juga sangat sensitif mempengaruhi tingkat penjualan. Apabila overload, maka aktivitas fulfillment center juga akan terganggu [4]. Untuk mengatasi hal tersebut, PT ABC melakukan peramalan harga jual produk di e-commerce PT XYZ. Peramalan merupakan sebuah cara untuk memprediksi masa depan dengan seakurat mungkin, menggunakan semua informasi yang tersedia, termasuk data historis dan peristiwa yang dapat memengaruhi peramalan [5]. Peramalan deret waktu melibatkan pengambilan model yang sesuai dengan data historis dan menggunakannya untuk memprediksi pengamatan di masa depan [6]. Beberapa metode untuk menyesuaikan model adalah box-jenkins ARIMA models, box-jenkins multivariate models, holt-winters, exponential smoothing (single, double, triple) [7].

Tingginya kompleksitas dalam penentuan peramalan harga jual suatu produk di e-commerce PT XYZ meruapakan landasan digunakannya proses simulasi untuk melakukan forecasting. Metode simulasi yang dipilih adalah metode simulasi monte carlo. Metode monte carlo merupakan dasar untuk semua algoritma dari metode simulasi yang didasari pada pemikiran penyelesaian suatu masalah untuk mendapatkan hasil yang lebih baik dengan cara memberi nilai sebanyak-banyaknya (nilai bangkitan/generated random number) untuk mendapatkan ketelitian yang lebih tinggi. 


\section{KAIZEN : MANAGEMENT SYSTEMS \& INDUSTRIAL ENGINEERING JOURNAL VOL. 3 NO. 1 TEKNIK INDUSTRI UNIVERSITAS PGRI MADIUN}

\section{Metode Penelitian}

Metode penelitian yang digunakan pada penelitian ini terbagi menjadi tiga buah tahap, yaitu, tahap pendahuluan, tahap pengumpulan data, dan tahap eksekusi. Detail dari metode penelitian disajikan pada Gambar 3. Beberapa asumsi yang digunakan pada penelitian ini adalah sebagai berikut

1. Simulasi yang dilakukan adalah simulasi harga jual produk A.

2. Data yang digunakan untuk melakukan simulasi harga jual produk A adalah nilai volatilitas data harga jual produk A yang diperoleh dari perubahan harga index jual produk A.

3. Proses simulasi tidak memperhatikan harga penyusun produk A. Hal tersebut dikarenakan uncontrollable value bersifat sangat dominan ketika simulasi dilakukan secara parsial.
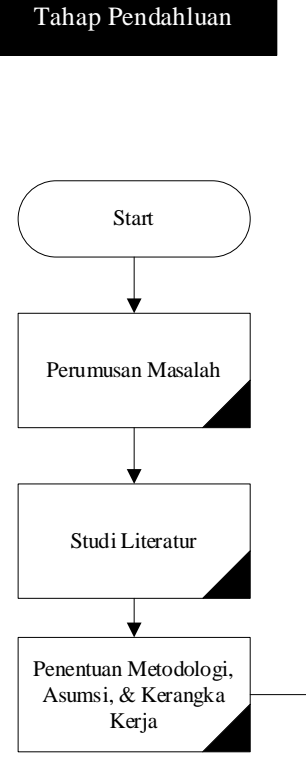

Tahap

Pengumpulan Data

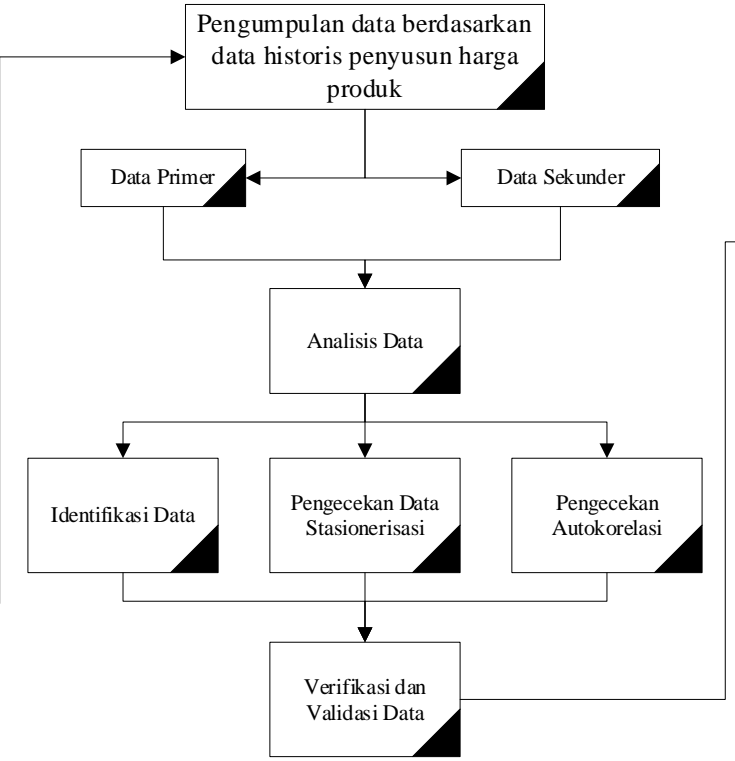

Gambar 3. Metode Penelitian
Tahap Eksekus

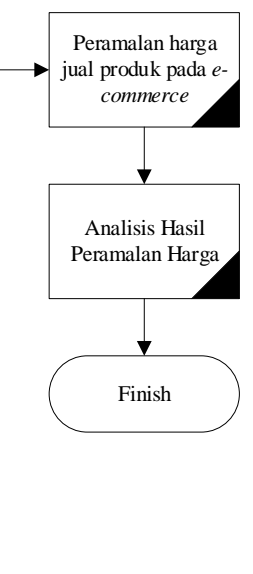

Tahap pendahuluan adalah tahapan yang digunakan untuk melakukan perumusan masalah hingga terbentuklah suatu maksud dan tujuan dari penelitian ini. Tahapan ini juga menunjukkan studi literatur yang digunakan sebagai landasan pemecahan masalah. Selain itu, tahapan ini juga digunakan untuk menentukan metodologi dan asumsi. Penjelasan kerangka kerja pada tahap pendahuluan sebagai berikut

1. Perumusan Masalah

Perumuan masalah adalah identifikasi permaslaah yang dilakukan pada penelitian ini. Identifikasi ini berisikan latar belakang penelitian, penyusunan maksud dan tujuan, merumuskan keluaran dari penelitian ini, serta pennetuan ruang lingkup atau batasan yang digunakan untuk melakukan penelitian pada perusahaan yang bersangkutan.

2. Studi Literatur

Studi literatur adalah pencarian terhadap berbagai sumber tertulis, baik berupa buku-buku, arsip, majalah, artikel, dan jurnal, atau dokumen-dokumen yang relevan dengan permasalahan yang dikaji. informasi yang didapat dari studi ini dijadikan rujukan untuk memperkuat argumentasi-argumentasi yang ada. Namun, pada penelitian yang dilakukan ini tidak hanya menggunakan studi literatur yang dipeoleh dari dokumen referensi yang sesuai. Pada penelitian ini juga menerapkan studi lapangan, studi lapangan adalah pengumpulan data dari perusahaan dengan mencatat data -data dari dokumen perusahaan. Aktivitas yang dilakukan pada studi lapangan ini berupa wawancara, pengumpulan data, hasil peramalan sebelumnya, metode yang digunakan sebelumnya, dan lain sebagainya.

3. Metodologi, Asumsi, dan Rencana Kerja

Metodologi adalah cara yang digunakan untuk memperoleh kebenaran menggunakan penelusuran dengan tata cara tertentu dalam menemukan kebenaran, tergantung dari realitas yang sedang dikaji. Pengertian lainnya adalah sebuah upaya sistematis dalam rangka pemecahan masalah yang dilakukan peneliti agar dapat menjawab permasalahan-permasalahan 


\section{KAIZEN : MANAGEMENT SYSTEMS \& INDUSTRIAL ENGINEERING JOURNAL VOL. 3 NO. 1 TEKNIK INDUSTRI UNIVERSITAS PGRI MADIUN}

atau fenomena yang terjadi. Asumsi adalah suatu skenario yang digunakan untuk melakukan simulasi situasi yang mungkin terjadi dengan memperhatikan berbagai faktor yang kompleks dan menyeluruh.

Tahap kedua adalah tahapan pengumpulan data, dimana tahapan ini terbagi menjadi dua buah aktivitas, yaitu, pengumpulan data primer serta sekunder dan analisis data. Data yang digunakan adalah data volatilitas harga jual produk A yang diperoleh dari perubahan harga index jual produk A. Data dinyatakan stasioner pada plot autokorelasi apabila 95\% dari data masuk ke dalam selang $\pm 1,96\left(\frac{1}{\sqrt{n}}\right)$. Jika data tidak stasioner pada nilai tengah, harus dilakukan proses konversi dengan cara melakukan diferensiasi, yaitu deret asli diganti dengan deret selisih. Jumlah diferensiasi yang dilakukan untuk mencapai stasioner dinotasikan sebagai $d$. Bentuk diferensiasi pertama $(\mathrm{d}=1)$ dinaytakan pada model Persamaan 1 .

$$
\nabla^{2} Z_{t}=Z_{t}-Z_{t-1}
$$

Bentuk diferensiasi kedua $(\mathrm{d}=2)$ adalah pada Persamaan 2.

$$
\nabla^{2} Z_{t}=\nabla Z_{t}-\nabla Z_{t-1}
$$

Keterangan

$Z_{t} \quad$ = pengamatan waktu ke-t

$Z_{t-1}=$ pengamatan waktu ke-(t-1)

$\nabla Z_{t} \quad=$ hasil diferensiasi pertama pada periode waktu ke-t

$\nabla Z_{t-1}=$ hasil diferensiasi pertama pada periode waktu ke-t-1

$\nabla^{2} Z_{t}=$ hasil diferensiasi kedua pada periode waktu ke-t

Setalah data dinyatakan stasioner, maka kita dapat melanjutkan menuju tahapan terakhir, yaitu, tahapan eksekusi. Tahapan eksekusi merupakan tahapan pengolahan data dan analisis hasil peramalan. Tahap pengelolaan data ini meliputi aktivitas perhitungan data berdasarkan data yang telah diverifikasi dan divalidasi sebelumnya. Setelah mengetahui hasil pengelolaan data, hasil data tersebut akan dianalisis. Analisis tersebut digunakan untuk mengetahui dan mengevaluasi hasil peramalan harga bahan baku jual produk A yang telah dilakukan dengan menggunakan Simulasi Monte Carlo. Simulasi Monte Carlo memiliki beberapa tahapan, disajikan pada Gambar 4.

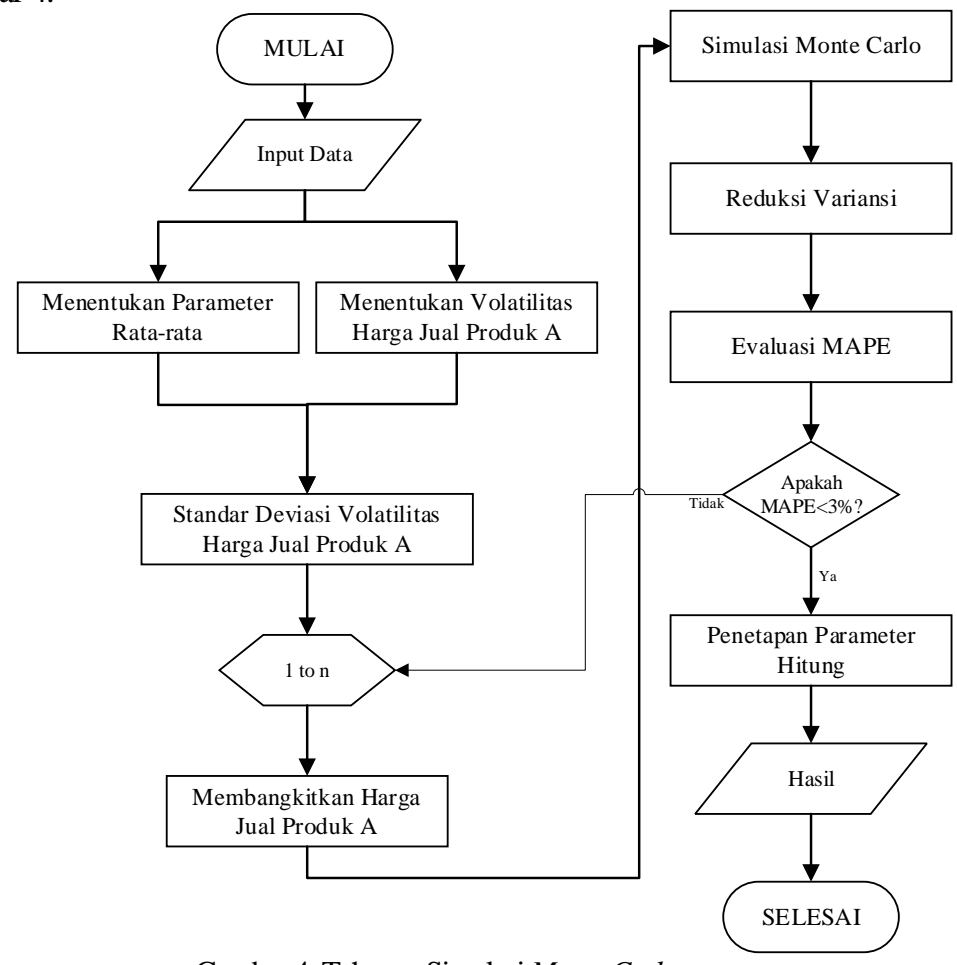

Gambar 4. Tahapan Simulasi Monte Carlo 


\section{KAIZEN : MANAGEMENT SYSTEMS \& INDUSTRIAL ENGINEERING JOURNAL VOL. 3 NO. 1 TEKNIK INDUSTRI UNIVERSITAS PGRI MADIUN}

\section{Hasil dan Pembahasan}

Metode terbaik yang digunakan untuk melakukan peramalan harga jual produk A adalah menggunakan Simulasi Monte Carlo. Simulasi ini akan melihat dan meniru pola data harga jual jual produk A sebelumnya yang ditampilkan dalam bentuk volatility (volatilitas). Volatilitas merupakan pergerakan indeks harga pada setiap satuan waktu. Dikutip dari penelitian yang dilakukan oleh Novitasati dan Setyawan tahun 2019, volatilitas merupakan perubahan suatu nilai konstanta pada suatu satuan waktu tertentu dari sebuah indeks harga jual dan selalu dievaluasi menggunakan suatu satuan waktu tertentu [8]. Cara untuk melakukan pengukuran volatilitas adalah dengan melakukan perhitungan standar deviasi dari perubahan nilai konstanta tersebut. Apabila perubahan nilai konstanta dari suatu waktu tidak signifikan, maka nilai standar deviasi akan kecil. Sebaliknya, apabila terjadi perubahan nilai yang ekstrim pada suatu waktu, maka nilai standar deviasi akan besar. Semakin besar nilai volatilitas maka akan semakin besar jumlah data awal yang dibutuhkan untuk melakukan simulasi. Simulasi monte carlo memerlukan beberapa langkah untuk dapat menyelesaikan permasalahan forecasting, yaitu

1. Analisis data

2. Menentukan parameter rata-rata dan standar deviasi data real harga jual produk A

3. Membangkitkan harga jual produk A

4. Menentukan harga opsi

5. Simulasi Monte Carlo standar

6. Menerapkan teknik reduksi variansi menggunakan metode variabel antithetik

7. Menentukan interval nilai opsi

Pada penelitian ini digunakan aplikasi microsoft excel dengan penambahan add-on excel crystal ball untuk melakukan simulasi monte carlo. Crystal ball merupakan suatu modul tambahan yang berjalan pada microsoft excel yang digunakan untuk melakukan proses simulasi. Cara kerja mendasar dari modul tersebut adalah membangkitkan bilangan acak yang digunakan sebagai variabel input proses simulasi monte carlo. Modul ini dipilih karena memiliki tampilan dan tahapan yang mudah untuk melakukan proses simulasi. Pada modul crystal ball, terdapat tiga jenis karakteristik sel, yaitu

1. Sel penentuan asumsi

2. Sel penentuan model keputusan

3. Sel penentuan model peramalan

Sel penentuan asumsi adalah nilai atau variabel yang tidak diketahui secara pasti masalah yang akan diselesaikan. Sel ini akan melakukan proses pembangkitan bilangan acak yang merupakan hasil dari sebuah distribusi probabilitas yang dapat di pilih, seperti; distribusi normal, distribusi seragam, distribusi eksponensial, distribusi geometrik, distribusi weibull, distribusi beta, distribusi hyper geometric, distribusi gamma, distribusi logistik, distribusi pareto, distribusi binominal, dan kustomisasi. Sel penentuan model keputusan bersisi nilai numerik yang digunakan sebagai conditional decision yang digunakan untuk mengontrol proses forecasting agar menjadi lebih optimal. Sel penentuan model peramalan merupakan sel yang berisi formula untuk melakukan proses forecasting dan terintegrasi dengan sel penentuan asumsi, dimana pada sel ini terdapat model matematika yang digunakan untuk melakukan proses peramalan. Tampilan lengkap dari add-on crystal ball disajikan pada Gambar 5.

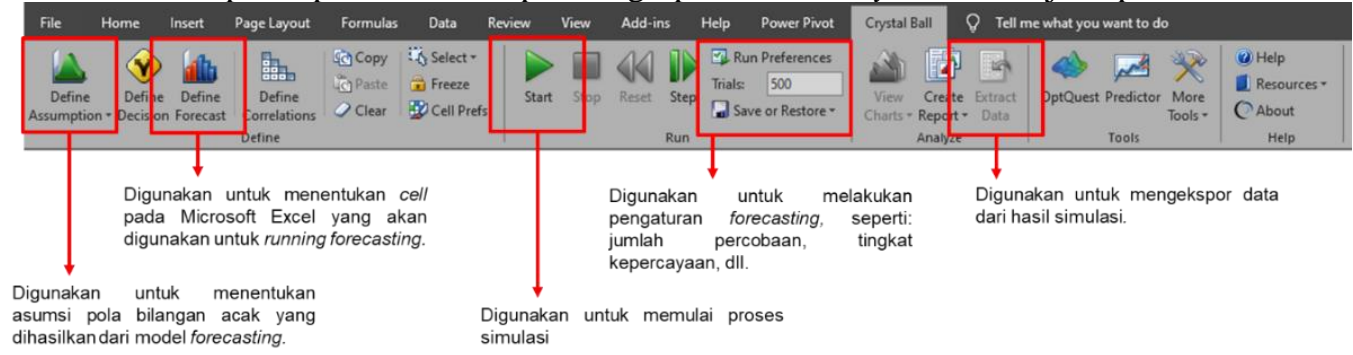

Gambar 5. Tampilan Add-on Crystal Ball pada Microsoft Excel

Simulasi monte carlo bergerak berdasarkan angka acak yang dibangkitkan dan akan bersinergi dengan model yang telah ditentukan. Angka acak pada penelitian ini dibangkitkan menggunakan distribusi triangle, dimana harus ditentukan angka acak minimum dan maksimum. Karena menggunakan "Pure Monte Carlo", maka angka acak minimum adalah 0, angka acak maksimum 1 dan angka acak yang paling sering muncul adalah 0,5.

Model forecast didefinisikan berdasarkan model input parameter dan model forecast. Model forecast dilakukan hingga 30 Juni 2020 dengan parameter data hingga 31 Juli 2019. Pendefinisikan model forecast digunakan model matematika pada Persamaan 3. Tabel 1. menjelaskan model Persamaan 3. 


\section{KAIZEN : MANAGEMENT SYSTEMS \& INDUSTRIAL ENGINEERING JOURNAL VOL. 3 NO. 1 TEKNIK INDUSTRI UNIVERSITAS PGRI MADIUN}

$$
\left[1+N O R M I N V\left(\text { rand_value } ; \sigma=\sqrt{\left.\left.k \frac{\sum_{t=1}^{n}\left(R_{t}-\bar{R}_{t}\right)^{2}}{n-1} 0 ;\right)\right)} \times \text { Price }_{t-1}\right]\right.
$$

Tabel 1. Penjelasan model persamaan

\begin{tabular}{|l|l|}
\hline \multicolumn{2}{|c|}{ Keterangan } \\
\hline Norminv & $\begin{array}{l}\text { Mengembalikan inversi distribusi kumulatif normal untuk rata rata dan simpangan baku } \\
\text { tertentu. }\end{array}$ \\
\hline Rand_value & $\begin{array}{l}\text { Diperoleh dari bilangan acak yang dibangkitkan pada tahap pertama (penentual sel asumsi), } \\
\text { yaitu, dengan menentukan angka acak 0 - } 1 .\end{array}$ \\
\hline Volatility $(\sigma)$ & Nilai standar deviasi pergerakan harga jual jual produk A dari waktu ke waktu \\
\hline
\end{tabular}

Volatilitas dinyatakan dengan simbol $\sigma$ yang merupakan setandar deviasi dari harga jual produk A dalam satuan hari. Nilai volatilitas berada pada interval skala nominal positif, antara 0 sampai tak terhingga $(0<\sigma<\infty)$. Semakin tinggi tingkat perubahan harga, maka akan semakin tinggi juga nilai volatilitasnya. Salah satu metode untuk mengestimasi volatilitas adalah dengan cara memetakan perubahan harga jual produk A dalam satuan hari. Perilaku pola perubahan historikal harga jual produk A, dapat digunakan untuk melakukan peramalan perilaku jual produk A di masa selanjutnya. Langkah untuk menghitung nilai volatilitas historis adalah sebagai berikut:

1. Mengambil sebanyak $n+l$ harga jual produk A, kemudian menghitung nilai log return.

2. Menentukan variansi $(\sigma)$ atau standar deviasi $\left(\sigma^{2}\right)$.

3. Menghitung volatilitas tahunan menggunakan Persamaan 4.

$$
\sigma=\sqrt{\mathrm{k} \frac{\sum_{\mathrm{t}=1}^{\mathrm{n}}\left(\mathrm{R}_{\mathrm{t}}-\overline{\mathrm{R}}_{\mathrm{t}}\right)^{2}}{\mathrm{n}-1}}
$$

Dimana $k$ adalah banyaknya periode perdagangan dalam satu tahun. Karena data pada penelitian ini adalah data harian, maka periode perdagangannya juga harian yaitu $\mathrm{k}=252$. Data volatilitas pada Tabel 2 . diperoleh dari nilai volatilitas pergerakan index harga jual produk A. Data volatilitas yang digunakan adalah dari periode 17 Agustus 2018 - 31 Juli 2019 karena pada periode tersebut data bersifat stasioner, dimana pada periode tersebut tidak terdapat outlier data. Berdasarkan Tabel 2, diperoleh nilai simpangan baku nilai volatilitas harga jual jual produk A sebesar 1,739753\%. Nilai volatilitas yang digunakan pada model adalah nilai volatilitas harian dengan Persamaan 5. Nilai volatilitas dari sampel yang telah dimiliki adalah 1,739753\%, sedangkan jumlah sample adalah 75, sehingga nilai volatilitas harian adalah 0,023197\% .

$$
\text { Daily Volatility }=\frac{\text { volatility sample }}{\text { number of sample }}
$$

Tabel 2. Volatilitas Harga Jual Produk A

\begin{tabular}{|c|c|c|c|c|c|c|c|c|c|}
\hline Periode & Volatilitas & Periode & Volatilitas & Periode & Volatilitas & Periode & Volatilitas & Periode & Volatilitas \\
\hline 1 & 1,826452696 & 16 & 1,838646263 & 31 & 3,131175955 & 46 & 0,910172621 & 61 & 1,568808905 \\
\hline 2 & 5,219899876 & 17 & 3,617910929 & 32 & 3,256992567 & 47 & 2,262978862 & 62 & 4,858960167 \\
\hline 3 & 1,578733825 & 18 & 4,2284086 & 33 & 1,997688795 & 48 & 3,411998149 & 63 & 3,967115384 \\
\hline 4 & 3,126337478 & 19 & 1,932052607 & 34 & 1,129353101 & 49 & 5,882903784 & 64 & 4,183844193 \\
\hline 5 & 4,668519894 & 20 & 0,904517256 & 35 & 5,436561694 & 50 & 3,69697485 & 65 & 1,518808441 \\
\hline 6 & 4,24810186 & 21 & 3,219422548 & 36 & 5,776771952 & 51 & 4,669966982 & 66 & 1,909579746 \\
\hline 7 & 3,280245654 & 22 & 4,034289392 & 37 & 0,665098692 & 52 & 0,669295627 & 67 & 5,669731507 \\
\hline 8 & 1,842283677 & 23 & 0,721448826 & 38 & 1,313756724 & 53 & 0,469927891 & 68 & 2,261566729 \\
\hline 9 & 5,026025952 & 24 & 0,461535573 & 39 & 5,948744077 & 54 & 3,641788534 & 69 & 5,813233506 \\
\hline 10 & 3,636842553 & 25 & 2,428988496 & 40 & 5,687662574 & 55 & 2,958140123 & 70 & 4,437217336 \\
\hline 11 & 4,865627426 & 26 & 1,73927089 & 41 & 4,159292186 & 56 & 0,503589494 & 71 & 3,788244936 \\
\hline 12 & 1,009976778 & 27 & 2,217693805 & 42 & 3,484846699 & 57 & 4,909698737 & 72 & 0,132674258 \\
\hline 13 & 0,620090761 & 28 & 3,438734073 & 43 & 5,635916859 & 58 & 4,613689306 & 73 & 4,097389919 \\
\hline 14 & 0,909810381 & 29 & 0,023423447 & 44 & 3,530230114 & 59 & 3,15079399 & 74 & 1,387293067 \\
\hline 15 & 0,219484476 & 30 & 1,745123372 & 45 & 0,617574587 & 60 & 5,903181498 & 75 & 4,408756312 \\
\hline
\end{tabular}




\section{KAIZEN : MANAGEMENT SYSTEMS \& INDUSTRIAL ENGINEERING JOURNAL VOL. 3 NO. 1 TEKNIK INDUSTRI UNIVERSITAS PGRI MADIUN}

Setelah tahapan penentuan input parameter dan decision parameter telah dilakukan, tahapan selanjutnya adalah melakukan simulasi. Proses simulasi dilakukan dengan melakukan percobaan sebanyak 1.000 kali percobaan. Simulasi dilakukan dengan melakukan 1.000 kali percobaan. Semakin banyak replikasi yang dilakukan, maka akan semakin akurat hasil simulasi yang diperoleh. Tingkat keakuratan simulasi diukur dari semakin kecilnya nilai MAPE dari harga jual produk A secara aktual. Dari 1.000 percobaan, percobaan ke-332 memiliki nilai MAPE terendah, yaitu, sebesar 0,122\%. Sepuluh percobaan dengan MAPE terendah disajikan pada Tabel 3. Sedangkan perbandingan harga asli terhadap hasil simulasi percobaan 332 disajikan pada Gambar 6.

Tabel 3. Evaluasi MAPE 10 Percobaan Terbaik

\begin{tabular}{|c|c|}
\hline Percobaan ke- & Nilai MAPE \\
\hline 332 & $0,124 \%$ \\
\hline 142 & $0,585 \%$ \\
\hline 353 & $1,022 \%$ \\
\hline 812 & $3,032 \%$ \\
\hline 312 & $3,122 \%$ \\
\hline 124 & $3,321 \%$ \\
\hline 53 & $3,398 \%$ \\
\hline 3 & $3,766 \%$ \\
\hline 145 & $3,893 \%$ \\
\hline 453 & $4,011 \%$ \\
\hline
\end{tabular}

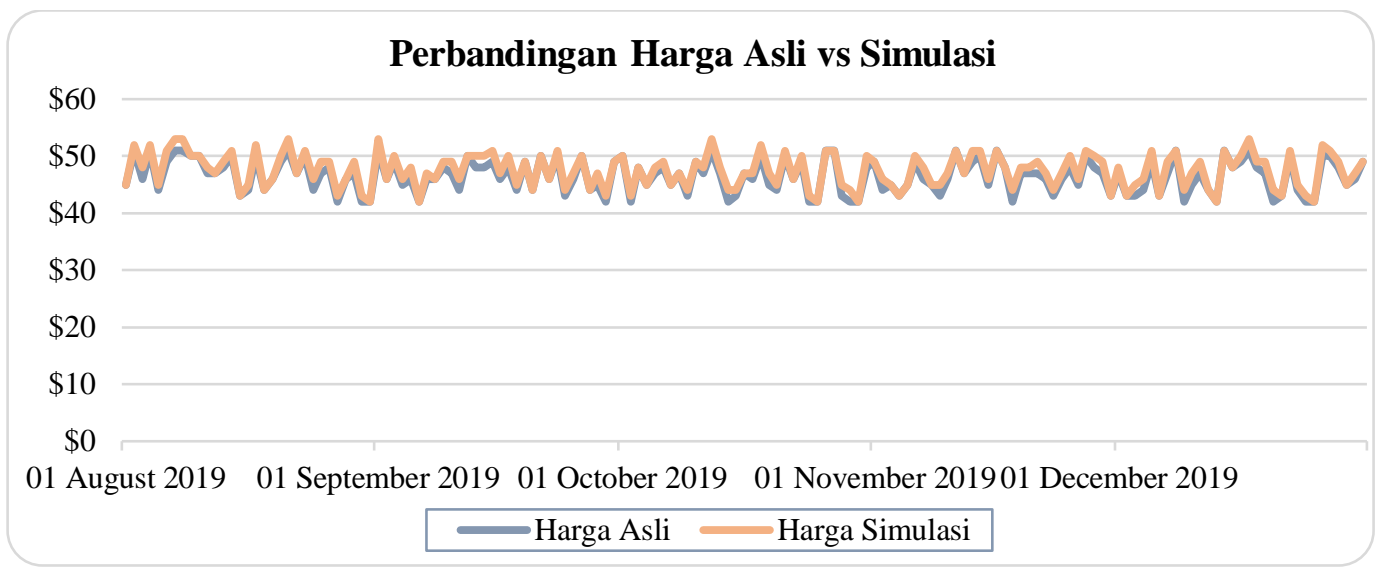

Gambar 6. Perbandingan Harga Asli terhadap Hasil Simulasi Percobaan 332

Proses forecasting dilakukan dengan menggunakan model simulasi monte carlo untuk mensimulasikan volatility dari harga jual produk A. Peneliti juga mengkaji menggunakan model forecasting independent model dalam melakukan proses forecasting. Perbedaan mendasar dari proses kedua model ini adalah dependensi variabel peramalan. Model simulasi monte carlo dependent memerlukan konstruksi model yang dipenden, misal, harga jual produk A dipengaruhi oleh komponen penyusun produk A, seperti, kurs dolar, harga komponen A1, komponen A2 dan komponen A3. Sedangkan model simulasi monte carlo independent, konstruksi model bersifat independent (hanya variabel akhir yang diperhatikan), sehingga harga komponen penyusun produk A tidak dipertimbangkan. Kelemahan dari model forecasting monte carlo dependent adalah data bersifast rigid, yaitu, tidak boleh terdapat data yang bersifat uncontrollable. Sedangkan pada penelitian ini, terdapat data uncontrollable, yaitu, nilai tukar Yuan dan USD terhadap IDR. Hal tersebut akan menyebabkan terjadinya deviasi antara hasil forecasting dengan aktual data, meskipun hasil forecasting memiliki nilai SSE (Sum Square Error) yang kecil dan memiliki pola forecast yang sama dengan harga asli. Fakta tersebut disajikan pada gambar di bawah ini, dimana, berdasarkan uji statistik, SSE yang dihasilkan menggunakan Monte Carlo Dependent adalah 1,23\%. Pola simulasi telah mengikuti pola data asli, namun memiliki deviasi yang sangat besar meskipun uji statistik menunjukkan nilai error yang kecil. Fenomena tersebut disajikan pada Gambar 7. 


\section{KAIZEN : MANAGEMENT SYSTEMS \& INDUSTRIAL ENGINEERING JOURNAL VOL. 3 NO. 1 TEKNIK INDUSTRI UNIVERSITAS PGRI MADIUN}

\section{Perbandingan Harga Asli vs Simulasi}

(Memperhatikan Dependent Variable)

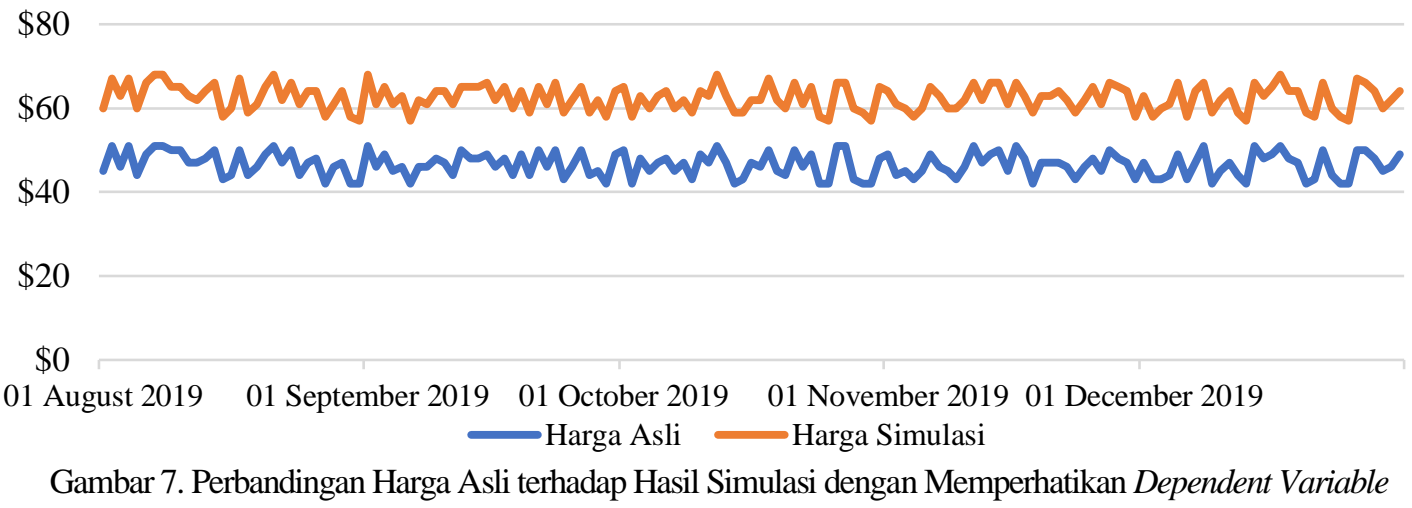

\section{Simpulan}

Dari hasil pengukuran HOR dari rantai pasok budidaya bibit udang vannamei disimpulkan bahwa 24 risk event (kejadian risiko) berdasarkan aktivitas SCOR yang terdiri dari bisnis "plan" (3 kejadian risiko), bisnis "source" (5 kejadian risiko), bisnis "make" (11 kejadian risiko), bisnis "deliver" (3 kejadian risiko) dan bisnis "return" (2 kejadian risiko). Hasil dari 22 risk agent berdasarkan perhitungan indeks prioritas ARP menggunakan model HOR fase 1, nilai tertinggi adalah kondisi cuaca yang tidak pasti (A3) dengan nilai ARP $=4606$, sedangkan nilai terendah adalah keterlambatan informasi dari pelanggan (A20) dengan nilai $\mathrm{ARP}=162$. Hasil pemetaaan dengan diagram pareto didapat 3 risk agent yang memiliki nilai ARP tinggi yaitu : kondisi cuaca yang tidak pasti (A3), kurangnya kedisiplinan pekerja (A14) dan kesalahan pekerja (A11). Model HOR fase 2 didapatkan penanganan mitigasi risiko untuk meminimalisir/menghindari terjadinya risk agent pada usaha dagang Jaya Makmur Abadi didapatkan 8 rekomendasi aksi mitigasi yang diprioritaskan. Aksi mitigasi dengan ranking tertinggi adalah melakukan pelatihan secara berkala yang memiliki nilai total keefektifan $\left(\mathrm{TE}_{\mathrm{k}}\right)$ sebesar 66324 , nilai keefektifan derajat kesulitan $\left(\mathrm{ETD}_{\mathrm{k}}\right)$ sebesar 22108 dan nilai derajat kesulitan $\left(D_{k}\right)$ adalah 3 yang berarti aksi mitigasi mudah diterapkan.

\section{Daftar Pustaka}

[1] E. B. Setyawan and N. Novitasari, "Indonesian High-Speed Railway Optimization Planning for Better Decentralized Supply Chain Implementation to Support e-Logistic Last Miles Distribution," in Journal of Physics: Conference Series, 2019, vol. 1381, pp. 1-6.

[2] H. Widowati, "Indonesia Jadi Negara dengan Pertumbuhan E-Commerce Tercepat di Dunia," 2019. [Online]. Available: https://databoks.katadata.co.id/. [Accessed: 30-Mar-2020].

[3] D. C. Chatfield and A. M. Pritchard, "Returns and The Bullwhip Effect," Transp. Res. Part E Logist. Transp. Rev., vol. 49, no. 1, pp. 159-175, 2013.

[4] E. B. Setyawan, D. D. Damayanti, and A. A. Kamil, "Multi-criteria Mathematical Model for Partial Double Track Railway Scheduling in Urban Rail Network," in IEEE International Conference on Industrial Engineering and Engineering Management, 2019, pp. 1416-1420.

[5] M. Zakria and F. Muhammad, "Forecasting The Population of Pakistan using ARIMA Models," Pak. J. Agri. Sci., vol. 46, no. 3, pp. 214-223, 2009.

[6] T. Nyoni, "Modeling and Forecasting inflation in Tanzania using ARIMA Models," in Munich Personal RePEc Archive, 2019, pp. 1-11.

[7] T. Nyoni, "Modeling and forecasting inflation in Lesotho using Box-Jenkins ARIMA Models," in Munich Personal RePEc Archive, 2019, pp. 1-11.

[8] N. Novitasari and E. B. Setyawan, "Decision Making in Inventory Policy Determination for Each Echelon to Stabilize Capsicum Frutescens Price and Increase Farmers Share Value Using Discrete Event Simulation," in Journal of Physics: Conference Series, 2019, vol. 1381, pp. 1-6. 